\title{
PERSPECTIVES FOR THE APPLICATION OF COMPUTER MODELS TO FOREST DYNAMICS FORECASTING IN BIESZCZADZKI NATIONAL PARK (POLAND)
}

\author{
IHOR KOZAK ${ }^{1}$, KAJETAN PERZANOWSKI ${ }^{2}$, STANISŁAW KUCHARZYK ${ }^{3}$, KRYSTYNA \\ PRZYBYLSKA ${ }^{4}$, STANISŁAW ZIĘBA ${ }^{4}$, RAFAŁ FRĄK ${ }^{1}$, LESZEK BUJOCZEK ${ }^{4}$
}

${ }^{1}$ Department of Landscape Ecology, John Paul II Catholic University in Lublin, Konstantynów 1H, 20-708 Lublin, Poland; e-mail: modeliho@kul.lublin.pl

${ }^{2}$ Department of Applied Ecology, John Paul II Catholic University in Lublin, Konstantynów1H, 20-708 Lublin, Poland; e-mail: StacjaKarpacka@miiz.waw.pl

${ }^{3}$ Bieszczadzki National Park, Bełzka 10, 38-700 Ustrzyki Dolne, Poland; e-mail: stku@o2.pl

${ }^{4}$ Chair of Forest Management, Agricultural University of Kraków, 29Listopada 46, 31-425 Kraków, Poland; e-mail: elkul@ar.krakow.pl

\begin{abstract}
Kozak I., Perzanowski K., Kucharzyk S., Przybylska K., Zięba S., Frąk R., Bujoczek L.: Perspectives for the application of computer models in forest dynamics forecasting in Bieszczadzki National Park (Poland). Ekológia (Bratislava), Vol. 33, No. 1, p. 16-25, 2014.

This paper presents the perspectives for application of computer models in forecasting the dynamics of forest development on example of Moczarne area, in Bieszczadzki National Park, based on authors' computer models. First, the possibilities for forecasting the dynamics of forest development in a local scale, i.e. within single rectangular or circular study plot, are presented. For this purpose, a computer prognostic model FORKOME has been applied, using both general mathematical relationships functioning within a forest ecosystem and empirical ones, characteristic for tree stands at analysed plots. Additionally, a layer of 3D visualisation of a tree stand, which is an integral part of the mentioned model, is also presented. Presented also are the possibilities for forecasting the dynamics of forest development at landscape scale, applying the theory of cellular automata. For this purpose, a prognostic computer model CELLAUT was used in which the whole analysed tree stand is understood as a set of single cells, where stages of landscape development dominating within those cells are considered as also the influence of particular cells upon their neighbours. The paper also describes the perspectives for application of self-learning neural networks in the process of supplementation and verification of some parameters of a tree stand, calculated by the above-mentioned models.
\end{abstract}

Key words: forest, Bieszczadzki National Park, FORKOME, CELLAUT, prognosis.

\section{Introduction}

The prognosis of the development of forest ecosystems can be performed at two different levels: at the local and landscape scale. At the local level, the development of a forest ecosystem is analysed within a single plot of relatively small dimensions (usually below $1 \mathrm{ha}$ ). A significant issue there is the determination of parameters of the stand (e.g. age of trees, their 
diameter at breast height) and the tendency for their changes in the course of consecutive years. At the landscape level however, development of a forest ecosystem within a large area is analysed. In this case, the prognosis for the development of tree stands growing within this area is significant, considering their species composition and external boundaries in precisely determined time intervals of the future.

Unfortunately, the prognostic process that includes all the above-mentioned aspects can be very complicated and time consuming, if it is done manually. Therefore, for such analysis, computer models of the forest landscape are very useful, which allow for much faster and efficient simulation of stand development on the basis of implemented algorithms. By all means, an ideal model should possibly, in the best way, reflect the structure of the stand and relationships dominating there, which justifies the use of both general relationships found and described by various authors, and relations determined empirically in a given ecosystem.

A model may provide, with an appropriate advancement, information on trends and relations existing in a forest ecosystem, and their potential effects in the future. That could allow for the application of preventive measures or proper cultivation, minimising the risk of a potential problem (e.g. an invasion of an undesirable species within a protected area that could lead to a disappearance of other, native tree species). A continuous improvement of prognostic landscape models may in the future make them the main planning tool of the forestry.

The main aim of this work is to present the perspectives for application of original FORKOME and CELLAUT computer models in forecasting the forest dynamics on example of Moczarne area in Bieszczadzki National Park.

\section{Methods}

Among the earliest computer models of the forest landscape were JABOWA (Botkin et al., 1972) and FORET (Shugart, West, 1977). They belong to the first models describing the dynamics of stand development and relations dominating there, simultaneously being able to predict changes taking place in the forest landscape. They are also the first patch models in the history. Among the later constructions of patch models of the forest landscape, based on those archetypes, include FORSKA (Leemans, Prentice, 1989; Prentice, Leemans, 1990), ZELIG (Urban, 1990; Urban et al., 1991), SORTIE (Pacala et al., 1993). In the last decade of the 20th century, there were 40 versions of such models, applied to forests from different vegetation-climatic zones (Bugmann, 2001). A pursuant of above-mentioned trend in modelling the evolution of forest ecosystems is the patch model FORKOME.

It is possible to identify two groups of processes occurring in patch models: phenomena taking place in the surroundings of a tree stand and its demographical processes. The basic temporal step applied in patch models is one year; changes in essential parameters of a tree stand are determined for subsequent steps. The length of total simulated period, applied in the model, depends only upon its planned, final credibility of the results (Brzeziecki, 1999). In models belonging to this group, the most optimal is the use of patches of about $600 \mathrm{~m}^{2}$ (Bugmann, 1994).

Model FORKOME (Kozak, Menshutkin, 1999) was constructed with an aim to simulate the dynamics in forest stands considering the fate of single trees. In this specific approach, the forest is treated as a group of trees, where each of them has an individual set of properties, and an individual development pattern. The model considers simulation of reproductive processes (block BIRTH), growth (block GROWTH) and mortality (block DEATH) of trees during every year, as well as the influence of additional environmental and ecological factors upon the tree stand. Among the factors considered are annual sum of precipitation (block PRECIP), annual sum of temperatures effective DGD (degree days) for vegetation (block TEMP), nitrogen contents in the soil (block NUTRIENT), degree of shading of the area (block LIGHT) by tree crowns (Kozak et al., 2003c).

All forested areas in the model FORKOME are analysed on the basis of the above-mentioned blocks, considering the actual increase of DBH (diameter at breast height) during the year of simulation (so-called DINC). DINC means an optimal increase of DBH, i.e. an increase of tree diameter in optimal conditions of environment ('ideal' 
increase). Hence, DBH is the fundamental parameter of trees on which the model FORKOME is based. Other significant parameters, e.g. the height of trees, are calculated on the basis of $\mathrm{DBH}$ value (in case when real data are missing). However, the actual increase of trees DINC has to take into account environmental conditions (annual sum of temperatures effective for vegetation; water balance connected with precipitation and transpiration; an average level of light availability in the forest; availability of nitrogen in the forest litter) which may reduce an optimal increase of DBH (DNC). Depending on dominating environmental conditions, every factor decreasing the optimal growth may take values between 0 and 1 .

Every reducing factor is represented by an appropriate thematic block. Since the time of its creation until now, the FORKOME model is constantly revised. Possibly the most recent achievements in the field of landscape modelling are implemented. This model was already used in scientific projects in various regions of Poland, for simulation of development and succession of mono- and multi-species stands according to different climatic scenarios, e.g. in Bieszczady (Kozak, Menshutkin, 2000a,b, 2001; Kozak et al., 2002, 2003b, 2007a), Ukrainian Eastern Beskydy (Kozak et al., 2005, 2007b) and Kampinos National Park (Kozak et al., 2003a).

Model FORKOME also contains continuously developed presentation layer, which allows for 3D visualisation of components of the forest landscape, including the layer of ground vegetation, dried and fallen trees, which is connected with simultaneously developed block of natural disasters (Fig. 1). At the present stage of the development of the model, components of visualisation have only presentational character and are not logically connected with thematic blocks of the model. However in a short perspective, the application of $3 \mathrm{D}$ visualisation in the process of an exact delineation of the shadow is also planned, based on the projection of tree canopy.

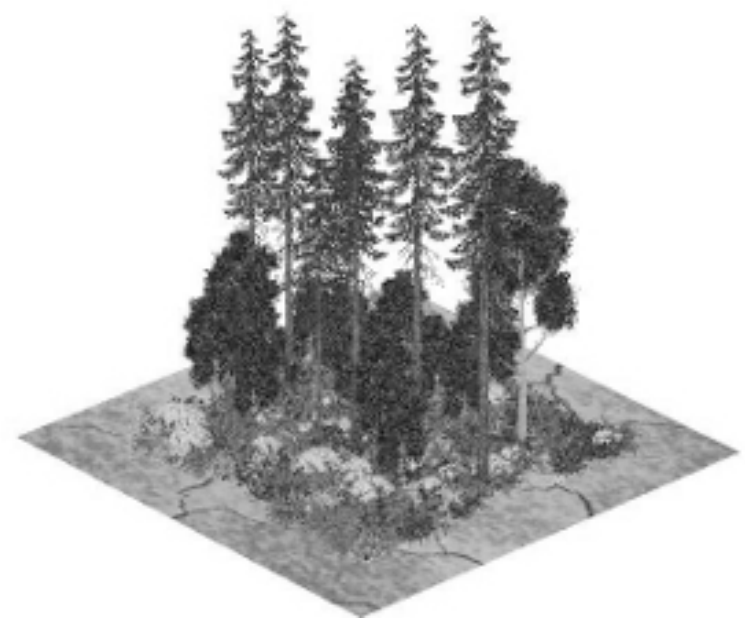

Fig. 1. 3D visualisation of exemplary forest plot from Moczarne, in the model FORKOME.

Unfortunately, when the dynamics of stand development is analysed within a larger, and more diversified area, 'patch' models may appear insufficient. Then, it is necessary to approach the whole analysed area as a set of mutually connected patches of tree stands. Additionally, a high degree of spatial differentiation within forest ecosystems causes that large-scale analyses of the dynamics of forest development with patch models would require setting a large number of study plots, which may be difficult due to many reasons.

In such case, a good idea can be the application of a mathematical theory of cellular automata, developed by John von Neumann and Stanislaw Ulam. A crucial component of this concept is a division of a large area into small cells, representing stages of landscape development, available from a finite list of such stages (a good example of a stage of landscape development can be a period of domination of a given tree species within one cell). For such approach, an important aspect is the determination of rules responsible for a transition of a given cell from one stage of development to the other in an appropriate time period, while the algorithm serving for determination of those rules should be possibly the most universal. 
The concept of cellular automata did not have at first any connection with biological sciences. However, because of the universal character of this theory, its practical applications in ecology, like the modelling of vegetation dynamics (Balzter et al., 1998; Colasanti, Grime, 1993) or population of insects (Hassel et al., 1991), were developed.

In forestry, the theory of cellular automata has found the application in modelling of a spread of forest fires (Karafyllidis, Thanailakis, 1997). In the field of landscape modelling however, regarding forest landscapes, the continuously developing model CELLAUT still functions (Kozak et al., 2003c).

Concluding, cellular automata used in landscape modelling consist of the following components: a regular grid containing a finite number of cells, rules for identification of neighbours (according to Neumann - four neighbouring cells, or according to Moor - eight neighbouring cells), function of transitions (determination of the status of cell $\mathrm{K}$ in the moment $t+1$, depending on the status of cell $\mathrm{K}$ and its neighbour in the moment $t$ ) and an initial configuration of cells' status (Kozak et al., 2003c).

Model CELLAUT has been elaborated for the simulation of the development of large landscape units, including forested areas. The specificity of this approach is a treatment of analysed forest area as a set of cells where each of them represents the stage of the landscape which dominates within its boundaries. The model is determined by a matrix of probabilities for landscape transitions on the basis of maps saved as text files, containing in fact a list of stages of landscape development for every cell within a given area in a determined moment of time.

Current version of the model requires two maps: first referring to the present status of cells and the second, the status of cells $n$ years before present. On the basis of those data, transition rules are determined depending on the status of cells and their neighbours (according to Neumann). Finally determined matrix, serves for the elaboration of prognosis of a large forest area, for $n$ years in advance.

Similar to FORKOME, the model CELLAUT also was already used in scientific projects for prognoses of a development dynamics for large areas of various characters (Seńko, Jóźwina, 2004; Frąk et al., 2009).

\section{Results}

To demonstrate the performance of the model FORKOME, a circular plot (No. 68672), with a radius of $14 \mathrm{~m}$ was used, situated in a tree stand within Moczarne area, in Bieszczadzki National Park at an elevation of $840 \mathrm{~m}$ a.s.l. Within the analysed plot, initially (in 2008), 29 trees belonging to species Abies alba and Fagus sylvatica (Fig. 2, Table 1) were recorded.

T a b l e 1. Initial characteristics of trees for simulated area in the model FORKOME.

\begin{tabular}{|l|c|c|c|}
\hline Species & Tree number & Basal area $\left(\mathbf{m}^{\mathbf{2}} \mathbf{h a} \mathbf{1}^{\mathbf{1}}\right)$ & Age (years) \\
\hline Fagus sylvatica & 22 & 5.4 & 24 \\
Abies alba & 7 & 9.2 & 122 \\
\hline
\end{tabular}

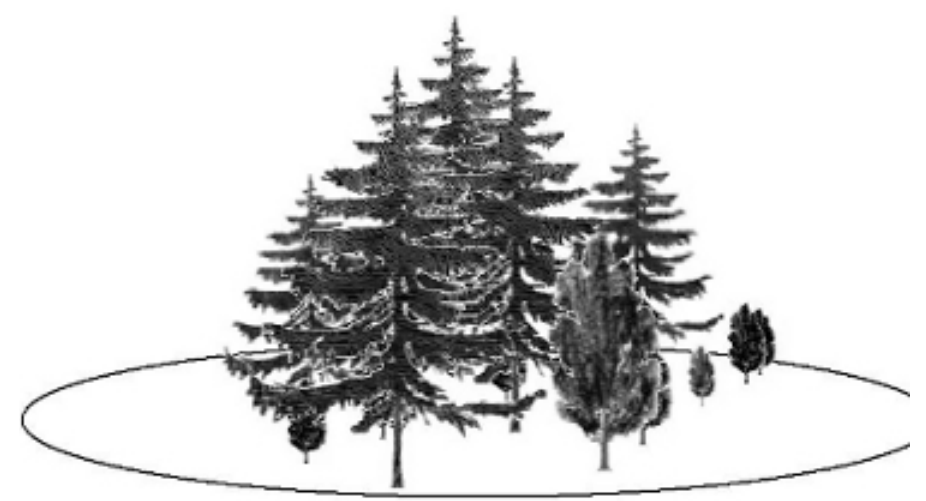

Fig. 2. Initial picture of simulated area in the model FORKOME (prior to the simulation). 
As a result of simulation, the proportion of beech trees considerably increased; the sum of DBH value for this species was finally higher than for fir. In terms of numbers, beech trees almost doubled compared to the first year of simulation, and reached 42 . The number of fir trees, however, remained at a similar level like at the beginning of simulation (Table 2).

T a b l e 2. Parameters of a tree stand in the 50th year of simulation by the model FORKOME.

\begin{tabular}{|l|c|c|c|}
\hline Species & Tree number & Basal area $\left(\mathbf{m}^{\mathbf{2}} \mathbf{h a}\right.$ & $\mathbf{1})$ \\
\hline Fagus sylvatica & 42 & 53.4 & Age (years) \\
Abies alba & 6 & 52 & 55 \\
\hline
\end{tabular}

Regarding the $\mathrm{DBH}$ values, a distinct domination of fir is visible, supplemented with young and many beech trees (Table 1). For this forest plot, a simulation of a stand development was performed for the next 50 years (Fig. 3).

In subsequent years of simulation, the proportion of beech trees (regarding the biomass) within an analysed area increases gradually but continuously from about $20 \%$ in the beginning, up to about $50 \%$ in the last year of simulation (Fig. 4).
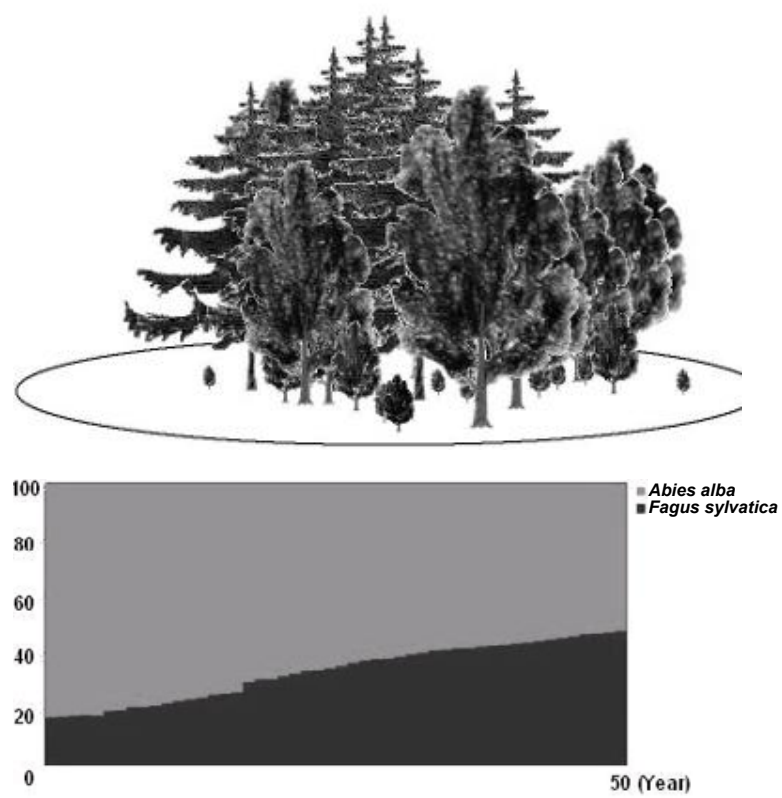

Fig. 3. Final picture resulting from simulation in the model FORKOME.
Fig. 4. Changes in the proportion of biomass of tree species in the studied tree stand forecasted by the model FORKOME (X-axis - year of simulation, Y-axis - a proportion of tree species in the biomass).

The analysis of tree stand development within a single patch cannot reflect the full picture of forest development dynamics, which is a larger area consisting of many patches. In such case, more credible results can be obtained with application of cellular automata in the form of CELLAUT model.

Unfortunately, on the basis of the dispersed 57 circular plots, it was not possible to construct a large, compact area consisting of square cells. Therefore, the performance of the 
model will be demonstrated using the stochastically generated, exemplary forest area (a square of $5 \times 5 \mathrm{~km}$, consisting of square cells $25 \times 25 \mathrm{~m}$ ) with tree species most frequently occurring there (beech and fir). The area was generated from two maps: present (year t0) and historic (year t0-50), considering the trend of dominance transition from fir to beech, observed in the simulation in FORKOME model, for the plot No. 68672 .

At first, the maps were imported, historic and present, and therefore, on their basis, the model could determine the transition matrix for landscape state during 50 years, considering both the changes within cells and the interaction among neighbouring cells. On the basis of transition matrix, the model creates the prognostic map for 50 years ahead $(t 0+50)$. A general scheme of prognosis for the dynamics of development of a large forest area with the use of CELLAUT model is given in Fig. 5. In the presented case, two stages of landscape development are identified: domination of beech (stage No. 1 - coloured dark grey) and domination of fir (stage No. 2 - coloured light grey). Obtained prognosis confirms the existence and continuity of a trend for the replacement of fir by beech in subsequent 50 years.

Such approach can also be applied in the simulation process of the dynamics of tree
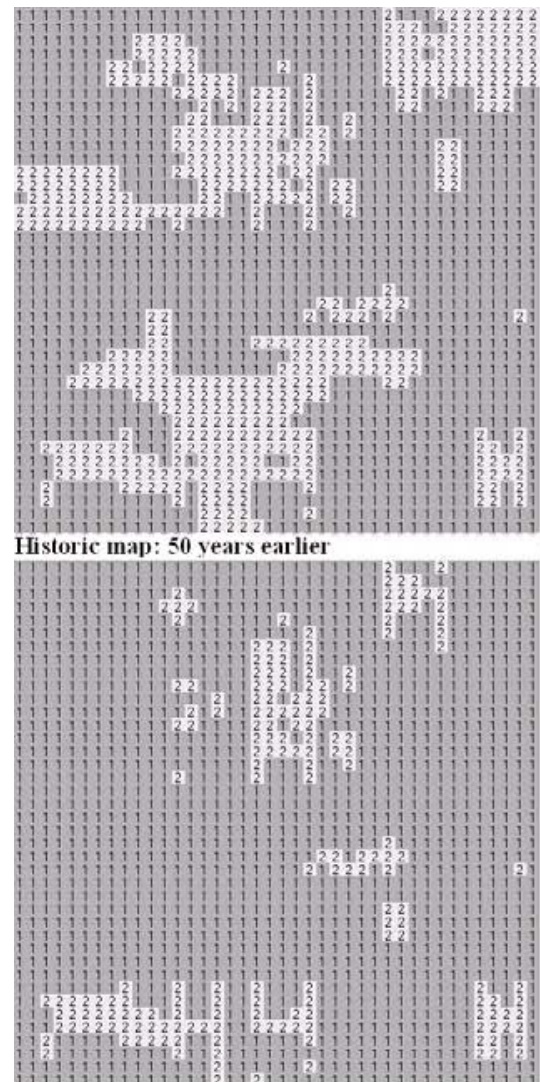

Determination of transition matrix

Present map-beginning of simulation
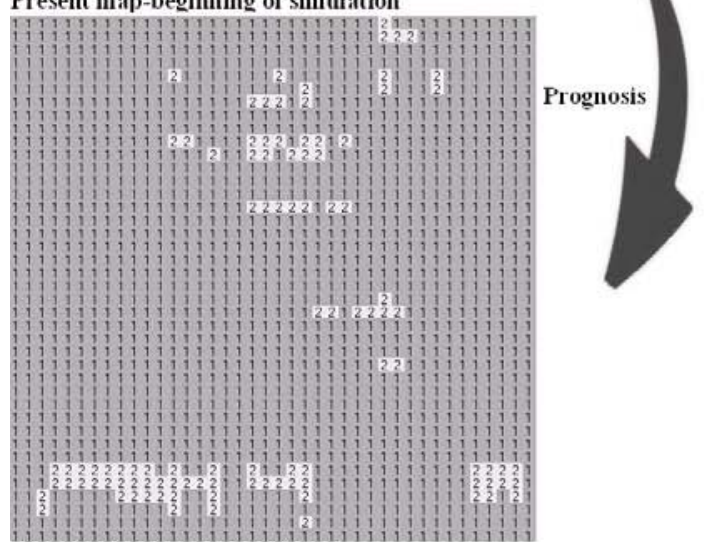

Prognostic man - 50 vears later

Fig. 5. Subsequent phases of simulation in the model CELLAUT (stage No. 1 - coloured dark grey - domination of beech; stage No. 2 - coloured light grey - domination of fir). 
stand development. At first, it is possible to verify, through a comparison of data generated by the model with data generated by the neural network, to what degree ecological relationships introduced to FORKOME model are true for a given area. For example, such situation may refer to an approximation of tree height value depending on its $\mathrm{DBH}$ value or prognosis of periodical increase of $\mathrm{DBH}$, height or the biomass of a tree depending on values of this parameter in the beginning of the analysed period. Application of a neural network could also be helpful to work along with CELLAUT model, in the prognostic process of changes in landscape status. In this case, input data can be assumed as the present state of considered cell and its neighbours, and the output data would be the state of this cell in the future. Such approach to a prognosis could allow for consideration of empirically confirmed relationships within analysed areas, influencing the state of simulated trees or cells.

\section{Discussion}

The study demonstrates the perspectives for the application of computer models in forecasting the dynamics of forest development (in a local scale with computer prognostic model FORKOME and at landscape scale using CELLAUT model).

The model FORKOME uses both general mathematical relationships functioning within a forest ecosystem, and empirical ones, characteristic for tree stands within analysed plots. That is, it combines ecological models (Brzeziecki, 1999; Bugmann, 2001) as well as empirical ones (Pretzsch et al., 2002). On the basis of results generated by the model, the hypothesis that in 50 years beech may become the dominant species within the analysed area regarding the number of trees as well as their biomass seems reasonable. That indirectly confirms the hypothesis that beech at Moczarne area is the main natural component of forest associations there (Michalik, Szary, 1997).

Additionally, within Bieszczadzki National Park, specific environmental conditions occur, which, as it has been proved, significantly influence the development of tree stands (e.g. slope exposition, elevation above sea level, relative insolation). Such analyses were already performed for a tree stand within an upper timberline in Bieszczadzki National Park (Kucharzyk, 2005), and in particular for dense beech stands there, being in a younger optimal phase (Kucharzyk, Sugiero, 2007), where such relation has been proved. At present, at Moczarne, similar analyses are conducted, aimed at determination of an exact relation between an increase of tree volume and selected environmental factors. Relations identified in this analysis will be included in the model FORKOME as a separate thematic block.

Presented also are the possibilities for forecasting the dynamics of forest development at landscape scale. For this purpose, a prognostic computer model CELLAUT was used, in which the whole analysed tree stand is understood as a set of single cells where dominating stages of landscape development within those cells are considered, and also the influence of particular cells upon their neighbours. That allows for the forecasting of the dynamics of vast forest landscapes where succession driven changes take place. In the literature, similar approaches applied for forecasting of changes in various components of the landscape are described (Karafyllidis, Thanailakis, 1997; Dunkerley, 1999). 
However, at the present stage of development, the CELLAUT model, in the prognostic process, does not consider certain factors characteristic for Bieszczadzki National Park, e.g. slope inclination and exposition, which may limit the accuracy of its prognosis. Additionally, it would be advisable to consider the effect of air pollution transferred by wind to Bieszczady area, which could become a significant detrimental factor for such sensitive species like fir. However, probably this factor could be neglected there for the time being, since fir stands in Bieszczady have higher degree of viability than stands growing to the west of Dunajec river, which most probably results from considerably lower amount of air pollution reaching as far as the Bieszczady region (Gawrońska, 2000). Nevertheless, the model CELLAUT will be systematically developed on the basis of currently conducted studies, extending to include a number of additionally considered factors.

Present results obtained with CELLAUT model are saved as ASCII files which is quite feasible for subsequent analysis regarding the aspect of metrics in landscape composition. In the CELLAUT model, there is a possibility for the calculation of spatial metrics patterns. However, obtained prognostic data saved as ASCII files can be easily used in other software packages like the FRAGSTATS (McGarigal, Marks, 1995), which is a specialist program used for the analysis of landscape metrics.

The paper also describes the perspectives for application of self-learning neural networks in the process of supplementation and verification of some parameters of a tree stand, calculated by the above-mentioned models. Artificial neural networks, which already find their application in natural sciences for many years (Lek, Guegan, 1999), are mathematical structures, and their program performs calculations through orders of elements called 'neurons'. Application of a neural network gives a possibility of describing unknown values of traits $Y 1, \ldots$, $Y m$ for a single object of a given class on the basis of known values of traits $X 1, \ldots, X n$ of this object. However, to start with, it is necessary to extract a sample of actual data on objects belonging to a given class, which will be used in the learning process for the neural network. For all objects composing a learning sample, all values of $X 1, \ldots, X n$ and $Y 1, \ldots, Y m$ should be known.

This modern approach, often finding an application increasingly in ecological studies, is also being gradually used in forest ecology. An attempt at the application of such approach to the analysis and prognosis of the dynamics of forest systems of Bieszczadzki National Park is already advanced and seems quite prospective. Through a comparison of data generated by both models and those generated by the neural network, it has been verified to what degree the ecological relationships considered by models FORKOME and CELLAUT are valid within a given plot. An example can be the issue of approximation of the tree height value depending on the value of its $\mathrm{DBH}$, and subsequently the forecasting of the periodical increase of $\mathrm{DBH}$ value, the height and the biomass of trees, depending on the value of this parameter in the beginning of the prognosis.

An additional possibility offered by the FORKOME model, connected with a layer of 3D visualisation of a tree stand, is its application to the calculation of spatial distribution of the shade of tree crowns within the patch area. This may appear to be very useful for the analysis of the process of tree regeneration.

An example of Bieszczady forests shows that computer simulation models in general, however, still require some refinement, and adaptation to a diversity of factors playing a role in forest 
ecology are becoming truly useful and a relatively inexpensive tool allowing for more precise planning in forest management.

\section{Conclusion}

Models FORKOME and CELLAUT are continuously improved and enriched with results of subsequent analyses which make them valuable and verified tools for the prognostic process of development dynamics of forest landscapes.

Both models supplement each other: model FORKOME works in a local scale, which allows for a detailed analysis of the characteristics of changes in the dynamics of forest development within a small patch of a tree stand. On the other hand, model CELLAUT working in a landscape scale allows for an analysis of a development dynamics of large forest areas, consisting of smaller, mutually neighbouring patches. Therefore in a perspective, an incorporation of both models into one integral entity may be planned.

A layer of 3D visualisation in the model FORKOME, apart from its presentational function, is also a nuclei for thematic blocks of the model, creation of which is planned in the future (e.g. determination of an exact extend of shaded area on the basis of the shape of tree crowns, and calculation of an influence of shading effect upon the growth of seedlings).

An additional element supplementing the performance of described models can be the application of neural networks, e.g. for verification and validation of obtained results, which may bring better fitness of those models to conditions and relationships occurring within various types of analysed forest areas.

\section{Acknowledgements}

Authors would like to sincerely thank the Directorate of Bieszczadzki National Park for help in obtaining data as well as for making available materials necessary for this work, and the Polish Ministry of Science and Higher Education for financing the project (KBN No. NN 309165937).

\section{References}

Balzter, H., Braun, P.W. \& Kohler W. (1998). Cellular automata models for vegetation dynamics. Ecol. Model., 107, 113-125. DOI: 10.1016/S0304-3800(97)00202-0.

Botkin, D.B., Janak, J.F. \& Wallis J.R. (1972). Some ecological consequences of a computer model of forest growth. J. Ecol., 60, 849-872. http://www.jstor.org/stable/2258570

Brzeziecki, B. (1999). Tree stand ecological model. Rules of construction, parameterization, examples of use (in Polish). Warszawa.

Bugmann, H. (1994). On the ecology of mountainous forests in a changing climate: a simulation study. PhD. thesis No. 10638, Swiss Federal Institute of Technology Zurich, Switzerland.

Bugmann, H. (2001). A review of forest gap models. Climatic Change 51. Kluwer Academic Publishers.

Colasanti, R.L. \& Grime J.P. (1993). Resource dynamics and vegetation processes: a deterministic model used two-dimensional cellurar automata. Funct. Ecol., 7, 169-176. http://www.jstor.org/stable/2389883

Dunkerley, D.L. (1999). Banded chenopod shrub lands of arid Australia: modeling responses to inter annual rainfall variability with cellular automata. Ecol. Model., 121, 127-138. DOI: 10.1016/S0304-3800(99)00088-5.

Frąk, R., Kozak, I., Widelska, E. \& Kozak H. (2009). Prognosis of landscape changes in the basin of the Bojarski stream with application of CELLAUT model (in Ukrainian). In Ecosystems of upper part of Prut river basin (pp. 246-252). Regional Conference, 15-17. 05. 2009. Lvov: Voroxta.

Gawrońska, G. (2000): An influence of atmospheric pollution upon forests of the Carpathian Region (in Polish). Rocznik Ochrony Środowiska, 2, 195-204. 
Hassel, M.P., Comins, H.N. \& May R.M. (1991). Spatial structure and chaos in insect population dynamics. Nature, 353, 255-258. DOI: 10.1038/353255a0.

Karafyllidis, I. \& Thanailakis A. (1997). A model for predicting forest fire spreading using cellular automata. Ecol. Model., 99, 87-97. DOI: 10.1016/S0304-3800(96)01942-4.

Kozak, I. \& Menshutkin V.V. (1999). Computer simulations of forest Ecosystems Dynamics. Biology Bulletin, 26(6), $586-592$.

Kozak, I. \& Menshutkin V. (2000a). Possibilities of application of computer modelling for prediction of tree stand succesion dynamics on the example of fir-beech tree stand in the Bieszczady Mountains. Forestry (Poland), 3, 113-122.

Kozak, I. \& Menshutkin V. (2000b). An investigation of forest succesion in Bieszczady Mountains using a computer models. Folia Forestalica Polonica, Series A - Forestry, 42, 67-81.

Kozak, I. \& Menshutkin V. (2001). Prediction of beech forest succesion in Bieszczady Mountains using a computer model. J. For. Sci. (Prague), 47, 333-339.

Kozak, I., Menshutkin, V., Jóźwina, M. \& Potaczała G. (2002). Computer simulation of fir forest dynamics in the Bieszczady Mountains in response to climate change. J. For. Sci. (Prague), 48, 425-431.

Kozak, I., Menshutkin, V., Ferchmin, M., Potaczała, G., Jóźwina, M., Kozak, O. \& Seńko Z. (2003a). Prognozowanie zmian lasu sosnowego w obszarze ochrony ścisłej Nart w Kampinoskim Parku Narodowym z wykorzystaniem modelu FORKOME. Parki Narodowe i Rezerwaty Przyrody, 22(4), 483-497.

Kozak, I., Menshutkin, V., Jóźwina, M. \& Potaczała G. (2003b). Modelling of beech forest dynamics in the Bieszczady Mountains in response to climate change. Ekológia (Bratislava), 22(2), 152-161.

Kozak, I., Menshutkin, V.V. \& Klekowski R.Z. (2003c). Modeling of landscape elements (in Polish). Lublin: Towarzystwo Naukowe KUL.

Kozak, I., Menshutkin, V., Parpan, V., Shparyk, Yu., Parpan, T., Viter, R., Kozak O. \& Seńko Z. (2005). Computer simulations of natural beech forest dynamics in the Boberka river basin in the Ukrainian Beskids. Natural Forests in the Temperate Zone of Europe - Values and Utilization (pp. 121-129). Birmensdorf: Published by Swiss Federal Research Institute.

Kozak, I., Chłódek, D., Zawadzki, A., Kozak, H. \& Potaczała G. (2007a). Conversion simulation of spruce stands in the Bieszczady mountains with the aid of FORKOME model (in Polish). Leśne Prace Badawcze, 2, 7-26.

Kozak, I., Parpan, V., Potaczała, G., Kozak, H. \& Zawadzki A. (2007b). Natural forest regeneration in spruce monocultures in the Ukrainian Beskids - prognosis by FORKOME model. J. For. Sci. (Prague), 53(4), 162-169.

Kucharzyk, S. (2005). An influence of the exposition and elevation above sea level upon the dynamics of forest stands at the upper timberline at Bieszczadzki National Park (in Polish). Roczniki Bieszczadzkie, 13, 173-201.

Kucharzyk, S. \& Sugiero D. (2007). A differentiation of the dynamics of reforestation processes in beech stands of Bieszczady, depending on the slope exposition and elevation (in Polish). Sylwan, 7, 29-38.

Leemans, R. \& Prentice I.C. (1989). FORSKA, a general forest succesion model. Uppsala: Meddelanden fran Vaxbiologiska Institutionen.

Lek, S. \& Guegan J.F. (1999). Artificial neural networks as a tool in ecological modelling, an introduction. Ecol. Model., 120, 65-73. DOI: 10.1016/S0304-3800(99)00092-7.

McGarigal, K. \& Marks B.J. (1995). FRAGSTATS. Spatial analysis program for quantifying landscape structure. USDA For. Serv. Gen. Tech. Rep. PNW-GTR-351.

Michalik, S. \& Szary A. (1997). Forest communities of Bieszczadzki National Park (in Polish). Monografie Bieszczadzkie 1.

Pacala, S.W., Canham, C.D. \& Silander J.A.J. (1993). Forest models defined by field measurements: I. The design of a northeastern forest simulator. Can. J. For. Res., 23, 1980-1988. DOI: 10.1139/x93-249.

Prentice, I.C. \& Leemans R. (1990). Pattern and process and the dynamics of forest structure: a simulation approach. J. Ecol., 78, 340-355. http://www.jstor.org/stable/2261116

Pretzsch, H., Biber, P. \& Durský J. (2002). The single tree-based stand simulator SILVA: construction, application and evaluation. For. Ecol. Manag., 162, 3-21. DOI: 10.1016/S0378-1127(02)00047-6.

Seńko, Z. \& Jóźwina M. (2004). CELAUT model perspective in landscape ecology (in Ukrainian). Visnyk of L’viv University. Series Geographical, 31, 333-339.

Shugart, H.H. \& West D.C. (1977). Development of an Appalachian deciduos forest model and its application to assessment of the impact of the chestnut blight. J. Environ. Manag., 5, 161-179.

Urban, D.L. (1990). A versatile model to simulate forest pattern: a user's guide to ZELIG version 1.0. Charlottesville, VA: University of Virginia, Environmental Sciences Department.

Urban, D.L., Bonan, G.B., Smith, T.M. \& Shugart H.H. (1991). Spatial applications of gap models. For. Ecol. Manag., 42, 95-110. DOI: 10.1016/0378-1127(91)90067-6. 